\title{
Kepatuhan Konsumsi Obat Kelasi Besi dan Kadar Feritin Serum Pasien Talasemia Beta-Mayor di RSUD Al-Ihsan Bandung
}

\author{
Hutari Gustiana, ${ }^{1}$ Tito Gunantara, ${ }^{2}$ Hilmi Sulaiman Rathomi ${ }^{3}$ \\ 1Program Studi Pendidikan Dokter, 2Departemen Ilmu Kesehatan Anak RSUD Al-Ihsan Bandung, \\ 3Departemen Ilmu Kesehatan Masyarakat Fakultas Kedokteran Universitas Islam Bandung
}

\begin{abstract}
Abstrak
Kadar feritin serum yang tinggi pada pasien talasemia menimbulkan berbagai komplikasi yang menurunkan kualitas hidup pasien. Kadar tersebut dipengaruhi oleh berbagai hal, salah satunya kepatuhan pasien dalam mengonsumsi obat kelasi besi. Penelitian ini bertujuan mengetahui tingkat kepatuhan konsumsi obat kelasi besi dan kadar feritin serum pada penderita talasemia beta-mayor di RSUD Al-Ihsan Bandung serta hubungan antara keduanya. Penelitian ini merupakan studi cross sectional dengan melibatkan 50 pasien talasemia di RSUD Al-Ihsan Bandung yang dipilih secara consecutive. Data tingkat kepatuhan diukur dengan kuesioner Morisky Medication Adherence Scale-8 (MMAS-8) yang diisi dipandu oleh peneliti, sedangkan data kadar feritin serum didapatkan dari rekam medis pasien. Pengambilan data dilakukan pada bulan Juli-September 2019, data dianalisis menggunakan uji chi square dengan bantuan piranti lunak STATA versi 13. Hasil penelitian menunjukkan mayoritas penderita talasemia beta-mayor di RSUD Al-Ihsan Bandung (60\%, IK 45,4-72,9\%) memiliki tingkat kepatuhan rendah dalam konsumsi obat kelasi besi dan sebagian besar memiliki kadar feritin serum $>2.500 \mathrm{ng} / \mathrm{mL}$ ( $58 \%$, IK 43,5-71,2\%). Terdapat hubungan bermakna secara statistik antara tingkat kepatuhan konsumsi obat kelasi besi dan kadar feritin serum pada penderita talasemia beta-mayor di RSUD Al-Ihsan Bandung $(\mathrm{p}=0,00)$.
\end{abstract}

Kata kunci: Feritin, kepatuhan minum obat, MMAS-8, talasemia $\beta$ mayor

\section{Drug Adherence of Iron-Chelating Agent and Serum Ferritin Levels of Beta- Major Thalassemia Patients in Al-Ihsan Hospital Bandung}

\begin{abstract}
High serum ferritin levels in thalassemia patients cause various complications that reduce the quality of life of patients. These levels are influenced by various things, one of which is patient compliance in consuming iron chelation. This study aims to determine the level of compliance with iron chelation drug consumption and serum ferritin levels in patients with beta-major thalassemia in Al-Ihsan Regional Hospital Bandung and the relationship between the two. This was a cross-sectional study involving 50 thalassemia patients at Al-Ihsan Regional Hospital Bandung, which was chosen consecutively. We measure the adherence by the Morisky Medication Adherence Scale-8 (MMAS-8) questionnaire, filled out with the researcher's guidance, while ferritin level data was obtained from the patient's medical record. Data was collected in July-September 2019, and data were analyzed using chisquare test with the help of STATA software version 13. The results showed the majority of patients with beta-major thalassemia in Al-Ihsan Regional Hospital Bandung (60\%, 45.4-72.9\% CI) have a low level of compliance in the consumption of iron chelation drugs and most have serum ferritin levels $>2.500 \mathrm{ng} / \mathrm{mL}$ (58\%, 43.5-71.2 CI). There was a statistically significant relationship between the level of compliance with iron chelation drug consumption with serum ferritin levels in patients with beta-major thalassemia in Al-Ihsan Regional Hospital Bandung $(p=0.00)$.
\end{abstract}

Keywords: $\beta$-major thalassemia, drug adherence, ferritin, MMAS-8

Korespondensi: Hilmi Sulaiman Rathomi, Departemen Ilmu Kesehatan Masyarakat, Fakultas Kedokteran Universitas Islam Bandung, Jl.Tamansari no. 22 40116, Kota Bandung. Email: hilmi.thomi@gmail.com. HP: o8112251649. 


\section{Pendahuluan}

Talasemia merupakan penyakit bawaan akibat mutasi gen yang menyebabkan gangguan sintesis satu atau lebih rantai globin. Perubahan ini mengakibatkan penurunan kadar Hemoglobin ( $\mathrm{Hb})$ dan perubahan bentuk sel darah merah. Dampaknya, pasien menjadi pucat pucat, sel darah merah (eritrosit) berukuran lebih kecil, dan siklus hidup eritrosit lebih pendek karena hemolisis ekstravaskular.

Anemia merupakan masalah utama pada penderita talasemia- $\beta$ mayor. Gejala anemia pada penderita talasemia dapat terlihat pada usia yang relatif dini. Untuk mengatasi hal ini, pasien biasanya perlu mendapatkan pemberian transfusi darah secara rutin. ${ }^{2}$ Transfusi darah rutin bertujuan mempertahankan kadar hemoglobin lebih dari $100 \mathrm{~g} / \mathrm{L}$.

Di sisi lain, transfusi darah secara rutin dapat menyebabkan kelebihan beban besi di beberapa organ. Hal ini terjadi karena dalam setiap $500 \mathrm{~mL}$ darah yang ditransfusikan dapat mengakibatkan akumulasi besi sebanyak kira-kira 200-250 mg di dalam tubuh. ${ }^{3}$ Kadar besi yang berlebih akan disimpan dalam bentuk feritin sehingga feritin akan mengalami peningkatan di dalam tubuh. Selain itu, peningkatan besi bebas atau non transferin bound iron (NTBI) bersifat radikal bebas yang dapat mepercepat kerusakan sel. ${ }^{4}$

Akumulasi feritin diakibatkan transfusi tersebut biasanya diantisipasi dengan pemberian obat kelasi besi pada pasien yang menjalani transfusi. Pemberian kelasi besi dimulai setelah mendapat transfusi darah sebanyak 20 kali atau saat kadar feritin serum lebih dari $1.000 \mu \mathrm{g} / \mathrm{L} .{ }^{5}$ Pemberian kelasi besi yang optimal penting dilakukan untuk menjaga kadar besi dalam batas normal.

Meskipun sangat dibutuhkan untuk mencegah kelebihan besi dalam tubuh, tingkat kepatuhan pasien terhadap konsumsi obat kelasi besi diduga relatif rendah. Kepatuhan yang rendah tersebut terjadi pada hampir semua pasien yang menjalani pengobatan dalam jangka panjang, khususnya terjadi di negara berkembang. Penelitian di India menyatakan bahwa di tingkat kepatuhan konsumsi obat kelasi besi di India amat rendah dan disertai dengan kadar feritin serum yang tinggi pada kelompok pasien yang tidak patuh. ${ }^{6}$

Sampai saat ini belum cukup banyak kajian mengenai tingkat kepatuhan terapi kelasi besi di Jawa Barat. Padahal, pengobatan yang optimal dapat memengaruhi kualitas hidup penderita talasemia. RSUD Al-Ihsan sebagai rumah sakit rujukan Provinsi Jawa Barat dinilai sebagai lokasi yang representatif untuk mendapatkan gambaran perilaku pasien talasemia di Jawa Barat. Untuk itu, penelitian ini bertujuan mengetahu tingkat kepatuhan konsumsi obat kelasi besi dan kadar feritin serum pada penderita talasemia beta-mayor di RSUD AI-Ihsan Bandung serta mengeksplorasi hubungan antara keduanya.

\section{Metode}

Penelitian ini merupakan penelitian observasional analitik dengan metode cross-sectional untuk mengetahui tingkat kepatuhan kosumsi obat kelasi besi, kadar feritin serum, serta hubungan antara keduanya pada pasien talasemia. Subjek penelitian merupakan pasien talasemia beta-mayor di RSUD AlIhsan Bandung. Sampel penelitian sebanyak 50 subjek yang dipilih dengan teknik consecutive sampling.

Instrumen pengambilan data pada penelitian ini menggunakan kuesioner standar Morisky Medication Adherence Scale-8 (MMAS-8) untuk mengukur tingkat kepatuhan pasien dalam konsumsi obat kelasi besi. Hasil pengukuran berdasar atas delapan item yang ada pada kuesioner tersebut diklasifikasikan menjadi kepatuhan rendah, sedang, dan tinggi. Sementara data kadar feritin serum pasien diambil dari data sekunder yang berasal dari rekam medis.

Pengambilan data penelitian ini dilaksanakan di RSUD Al-Ihsan Bandung pada bulan Juli-September 2019. Analisis data dilakukan dengan menggunakan program STATA versi 13 dengan uji chi-square pada derajat kepercayaan 95\% dan nilai $\mathrm{p} \leq 0,05$. Penelitian ini telah mendapatkan izin etik dari Komite Etik Penelitian Kesehatan Fakultas Kedokteran Universitas Islam Bandung No. 16o/Komite Etik.FK/IV/2019.

\section{Hasil}

Subjek penelitian ini adalah 50 orang pasien talasemia beserta orangtua pasien yang juga menjadi responden. Orangtua pasien dilibatkan dalam pengisian kuesioner khususnya bagi pasien yang masih berusia balita dan usia sekolah. Karakteristik subjek penelitian dan orangtua pasien dalam penelitian ini dapat dilihat pada Tabel 1.

\section{Tabel 1 Karakteristik Responden}

\begin{tabular}{llcc}
\hline \multicolumn{1}{c}{ Karakteristik } & n & \% \\
\hline Usia orangtua & $<40$ & 29 & 58 \\
(tahun) & $\geq 40$ & 21 & 42 \\
Penghasilan & >Rp2.890.000 & 12 & 24 \\
orangtua & $<$ Rp2.890.000 & 38 & 76 \\
& BPJS non PBI & 30 & 60 \\
Pembiayaan & BPJS PBI & 20 & 40 \\
& Bekerja & 17 & 34 \\
Pekerjaan orangtua & Tidak bekerja & 33 & 66 \\
& 3-6 & 18 & 36 \\
Usia pasien & $7-12$ & 23 & 46 \\
(tahun) & $13-20$ & 9 & 18 \\
& Tidak sekolah & 20 & 40 \\
Pendidikan pasien & SD & 25 & 50 \\
& SMP & 4 & 8 \\
& SMA & 1 & 2 \\
Durasi sakit & $<10$ & 38 & 76 \\
(tahun) & $\geq 10$ & 12 & 24 \\
Riwayat saudara & Tidak & 42 & 84 \\
talasemia & Ya & 8 & 16 \\
\hline
\end{tabular}

Tabel 1 menunjukkan karakteristik orangtua penderita talasemia beta-mayor di RSUD Al-Ihsan Bandung. Mayoritas orangtua berusia <40 tahun dengan usia termuda 22 tahun. Proporsi orangtua dengan penghasilan kurang dari UMR (Rp2.890.000) jauh lebih besar dibanding dengan yang lebih dari UMR. Pembiayaan responden sebagian besar menggunakan BPJS golongan PBI (60\%) dan tidak ada 
yang menggunakan metode out of pocket. Lebih dari setengah orangtua pasien juga tidak bekerja.

Usia pasien paling banyak berada pada kelompok usia 7-12 tahun, yaitu berjumlah 23 orang (46\%). Sebanyak 25 orang (50\%) responden memiliki tingkat pendidikan sekolah dasar dan yang tidak sekolah sebanyak 40\%. Berdasar atas durasi sakit responden yang mengalami durasi sakit $<10$ tahun berjumlah 38 (76\%). Responden yang memiliki riwayat saudara dengan talasemia berjumlah 8 orang(16\%).

Tabel 2 Distribusi Tingkat Kepatuhan Minum Obat Kelasi Besi pada Penderita Talasemia Beta-Mayor

\begin{tabular}{lccc}
\hline Tingkat Kepatuhan & $\mathbf{n}$ & $\mathbf{\%}$ & IK 95\% \\
\hline Rendah & 30 & 60 & $45,4-72,9$ \\
Sedang & 10 & 20 & $10,9-33,9$ \\
Tinggi & 10 & 20 & $10,9-33,9$ \\
\hline
\end{tabular}

Tabel 2 menunjukkan karakteristik responden penelitian berdasar atas tingkat kepatuhan minum obat. Mayoritas pasien memiliki tingkat kepatuhan rendah (60\%), sedangkan pada kategori sedang dan tinggi memiliki jumlah yang sama, yaitu $20 \%$.

Tabel 3 Distribusi Kadar Feritin Serum pada Penderita Talasemia Beta-Mayor

\begin{tabular}{cccc}
\hline Kadar Feritin Serum & $\mathbf{n}$ & $\mathbf{\%}$ & IK 95\% \\
\hline$\leq 2.500$ & 21 & 42 & $28,8-56,4 \%$ \\
$>2.500$ & 29 & 58 & $43,5-71,2 \%$ \\
\hline
\end{tabular}

Karakteristik kadar feritin serum menunjukkan bahwa sebagian besar penderita talasemia betamayor di RSUD Al-Ihsan Bandung memiliki kadar feritin serum di atas $2.500 \mathrm{ng} / \mathrm{mL}$, yaitu sebanyak 29 responden (58\%). responden. Penelitian ini memiliki karakteristik kategori usia yang sama dengan penelitian Lukas dkk. ${ }^{7}$ diperoleh responden berusia 6-11 tahun sebanyak 44,6\%. Berdasar atas pendidikan, sebagian besar responden masih bersekolah di SD sebanyak 25 responden (50\%) dan yang tidak sekolah 20 responden (40\%). Karakteristik pendidikan yang sama pada penelitian Safitri dkk. mayoritas penderita talasemia beta-mayor berpendidikan SD sebanyak 35,7\% dan jumlah penderita talasemia yang tidak sekolah lebih rendah sebanyak 1 orang $(1,8 \%)$.

Berdasar atas durasi sakit pada penderita talasemia beta-mayor didapatkan sejumlah 38 responden $(76 \%)$ memiliki durasi sakit $<10$ tahun. Hasil yang sama diperoleh pada penelitian yang dilakukan oleh Tejasari dkk. ${ }^{8}$ yang menunjukkan bahwa mayoritas penderita talasemia beta-mayor memiliki durasi sakit $<10$ tahun, sedangkan persentase penderita dengan durasi sakit $\geq 10$ tahun sebanyak $31 \%$.

Status ekonomi keluarga yang tinggi akan meningkatkan kualitas hidup anak penderita talasemia. Semakin tinggi tingkat status ekonomi keluarga akan meningkatkan perhatian terhadap kesehatan anak. ${ }^{9}$ Berdasar atas penelitian ini didapatkan sebagian besar pendapatan orangtua per bulan sebesar $<$ Rp2.890.000. Hasil yang sama diperoleh pada penelitian yang dilakukan Aji dkk..$^{10}$ mayoritas $(54,6 \%)$ memiliki penghasilan menengah.

Pada penelitian ini mayoritas penderita talasemia beta-mayor di RSUD Al-Ihsan mempunyai tingkat kepatuhan minum obat kelasi besi yang rendah, yaitu sebanyak 30 responden (60\%). Hasil ini lebih baik bila dibanding dengan penelitian di India yang menunjukkan bahwa jumlah responden dengan tingkat kepatuhan tinggi hanya berjumlah 7 dari 91 responden(7.5\%). ${ }^{6}$ Penelitian lain yang dilakukan oleh Arifna dkk. ${ }^{11}$ di sentral talasemia RSUD dr Zainal Abidin Banda Aceh mengenai tingkat kepatuhan minum obat kelasi besi menggunakan instrumen kuesioner yang sama menunjukkan hasil yang sama bahwa sebanyak

\section{Tabel 4 Hubungan Tingkat Kepatuhan Minum Obat Kelasi Besi dengan Kader Feritin Serum}

\begin{tabular}{ccccccc}
\hline \multirow{2}{*}{ Tingkat Kepatuhan } & \multicolumn{5}{c}{ Kadar Feritin Serum } & Nilai p \\
\cline { 2 - 5 } & $\mathbf{n}$ & $\mathbf{< . 5 0 0}$ & $\mathbf{\%}$ & $\mathbf{n}$ & $\mathbf{2 . 5 0 0}$ & \\
\hline Rendah & 5 & 17 & 25 & 83 & 0.00 \\
Tinggi & 16 & 80 & 4 & 20 & 58 \\
Total & 21 & 42 & 29 & 58 & \\
\hline
\end{tabular}

Pada Tabel 4 didapatkan nilai $\mathrm{p}=0,00 \quad(\mathrm{p}<0,05)$ dengan menggunakan uji chi-square sehingga dapat disimpulkan secara statistik terdapat hubungan signifikan antara tingkat kepatuhan dan kadar feritin serum. Selain itu, Tabel 4 menunjukkan bahwa mayoritas responden dengan kepatuhan rendah memiliki kadar feritin serum di atas $2.500 \mathrm{ng} / \mathrm{mL}$ sebanyak 25 responden (83\%).

\section{Pembahasan}

Pada penelitian ini, mayoritas responden penderita talasemia beta-mayor di RSUD Al-Ihsan Bandung tahun 2019 berusia $7-12$ tahun yang berjumlah $46 \%$
$60,5 \%$ memiliki tingkat kepatuhan minum obat kelasi besi yang rendah. Selain itu, sebanyak 15 pasien dari 26 (57,7\%) dengan kepatuhan minum obat rendah mengalami keterlambatan dalam kematangan seksual seksual.

Terdapat beberapa faktor yang memengaruhi kepatuhan pengobatan diantaranyaadalah penggunaan obat yang tidak tepat, kualitas informasi tentang pengobatan, regimen pengobatan yang kompleks, dan intoleransi yang ditimbulkan dari pengobatan. Selain itu, ketidakpatuhan dalam pengobatan dapat diakibatkan oleh faktor disengaja atau tidak disengaja, faktor disengaja meliputi komunikasi yang buruk, efek samping, serta ketidakpercayaan tentang pengobatan, 
sedangkan faktor tidak disengaja biasanya karena lupa atau kesulitan dalam memahami instruksi. ${ }^{12}$

Pada penelitian ini kadar feritin serum pada penderita talasemia beta-mayor di RSUD Al-Ihsan Bandung diperoleh sebanyak 29 responden (58\%) memiliki kadar feritin serum di atas $2.500 \mathrm{ng} / \mathrm{mL}$. Hasil ini sejalan dengan penelitian yang dilakukan oleh Fadlyana dkk..$^{13}$ di RSHS Bandung yang menunjukkan sebanyak 71 responden (77\%) memiliki kadar feritin serum $>2.500 n g / \mathrm{mL}$. Selain itu, pada penelitian yang dilakukan oleh Satria dkk. ${ }^{14}$ di RSUD Arifin Achmad Riau juga menunjukkan 39 responden (66,1\%) memiliki kadar feritin serum $>2.500 n g / m L$. Pada penelitian ini diperoleh bahwa tingginya kadar feritin serum tidak memiliki hubungan dengan beratnya klinis pada penderita talasemia.

Kadar feritin serum yang tinggi berhubungan dengan kelebihan besi di hati, baik pada kelompok transfusion dependent thalassemia (TDT) dan non transfusion dependent thalassemia (NTDT). Kadar feritin serum $<300 \mathrm{ng} / \mathrm{mL}$ merupakan nilai batas untuk menandakan tidak terjadi kelebihan besi, sedangkan kadar feritin serum $>800 \mathrm{ng} / \mathrm{mL}$ secara klinis signifikan menyebabkan kelebihan besi di dalam tubuh. Selain itu, kadar feritin serum $>2.500 \mathrm{ng} /$ $\mathrm{mL}$ dapat menimbulkan penimbunan besi di jantung dan gangguan endokrin. Pada nilai kadar feritin serum $>1.000 \mathrm{ng} / \mathrm{mL}$ merupakan indikasi untuk pemberian terapi kelasi besi, sedangkan kadar feritin serum $<1.000 \mathrm{ng} / \mathrm{mL}$ berhubungan dengan tingkat morbiditas dan mortalitas yang rendah pada kelompok transfusion dependent thalassemia (TDT)..$^{15}$

Hasil uji statistik chi-square terdapat hubungan yang sifnifikan antara tingkat kepatuhan minum obat kelasi besi dan kadar feritin serum $(\mathrm{p}=0,00)$. Hasil ini sejalan dengan penelitian di India yang menunjukkan hubungan signifikan antara kadar feritin serum dan kelompok kepatuhan yang berbeda terhadap konsumsi obat kelasi besi, diperoleh hasil uji one-way ANOVA $(\mathrm{p} \leq 0,005){ }^{6}$

Pada penelitian ini mayoritas responden memiliki kadar feritin serum di atas $2.500 \mathrm{ng} / \mathrm{mL}$, nilai tersebut berdasar hasil penelitian Fadlyana dkk. ${ }^{13}$ di RSHS Bandung bahwa terdapat hubungan signifikan kadar feritin serum di atas $2.500 \mathrm{ng} / \mathrm{mL}$ dengan gangguan pertumbuhan $(p=0,03)$. Selain itu, tingkat pertumbuhan yang baik pada anak penderita talasemia juga dipengaruhi oleh tingkat kepatuhan yang tinggi terhadap konsumsi obat kelasi besi. Hal tersebut ditunjukkan oleh penelitian oleh Lukas dkk. ${ }^{7}$ bahwa terdapat hubungan yang signifikan tingkat kepatuhan konsumsi obat kelasi besi dengan tingkat pertumbuhan anak penderita talasemia $(\mathrm{p}=0,021)$.

Kadar feritin serum di atas $2.500 \mathrm{ng} / \mathrm{mL}$ juga berhubungan dengan risiko tinggi terkena penyakit jantung yang berujung pada kematian pada penderita talasemia, didapatkan $67 \%$ kematian pada penderita talasemia diakibatkan oleh kelebihan besi yang mengakibatkan gagal jantung dan aritmia. ${ }^{16}$ Kepatuhan konsumsi obat kelasi besi yang tinggi selain mencegah komplikasi juga telah menurunkan biaya perawatan penderita talasemia.

\section{Simpulan}

Mayoritas pasien talasemia beta mayor di RSUD Al Ihsan memiliki tingkat kepatuhan konsumsi obat yang rendah dan kadar feritin serum yang amat tinggi. Terhadap hubungan antara tingkat kepatuhan konsumsi obat kelasi besi dan kadar feritin serum pada pasien penderita talasemia beta mayor.

\section{Ucapan Terima Kasih}

Ucapan terima kasih kepada karyawan bagian Cancer Centre RSUD Al Ihsan Kota Bandung yang telah memfasilitasi proses pengambilan data pada penelitian ini.

\section{Daftar Pustaka}

1. Kumar V, Abbas AK, Aster JC, Robbins SL. Robbins basic pathology. Philadelphia, PA: Elsevier/Saunders; 2013.

2. Cappellini MD. 162 - The thalassemias. GoldmanCecil Med. 2016:1089-1095.e2. doi:10.1016/B9781-4557-5017-7.00162-8

3. Hoffbrand AV, Moss P, Hoffbrand AV. Hoffbrand's essential haematology. Edisi ke-7. John Wiley \& Sons, Ltd, The Atrium, Southern Gate, Chichester, West Sussex, PO19 8SQ, UK. 2016.

4. Taher A, Nathan D, Porter J. Evaluation of iron levels to avoid the clinical sequelae of iron overload. Semin Hematol. 2007;44(SUPPL. 3):26. doi:10.1053/j.seminhematol.2007.03.002

5. Temraz S, Santini V, Musallam K, Taher A. Iron overload and chelation therapy in myelodysplastic syndromes. Crit Rev Oncol Hematol. 2014;91(1):64-73. doi:10.1016/j. critrevonc.2014.01.006

6. Health WE, Health O. Adherence to deferasirox among beta-thalassemia major children - a crosssectional study in a tertiary care hospita. Indian J Child Heal. 2010;36(1):2016-9. doi:10.1089/ten. tea.2015.0461

7. Lukas S, Nugroho H, Ellora Sudarman V. Correlations between oral iron chelation therapy adherences with thalassemia children's growth in Anna Medika Hospital. Sci Int (Lahore). 2018;30(2):247-52.http://www.sci-int.com/ pdf/636579332591484419.edited=Aneela.pdf.

8. Tejasari RK, Reniarti L, Effendi SH. Faktor risiko hiperkoagulasi pada thalassemia anak. Sari Pediatr. 2016;16(6):427. doi:10.14238/ sp16.6.2015.427-33

9. Yanitawati, Mardhiyah AI, Widianti E. Hubungan perilaku sakit dalam aspek psikososial dengan kualitas hidup remaja thalasemia. J Keperawatan BSI. 2017;5(1):38-47. http://ejournal.bsi.ac.id/ ejurnal/index.php/jk 39.

10. Aji DN, Silman C, Aryudi C, Cynthia, Centauri, Andalia D, dkk. Faktor-faktor yang berhubungan dengan kualitas hidup pasien thalassemia mayor di Pusat Thalassemia Departemen Ilmu Kesehatan Anak RSCM. Sari Pediatr. 2009;11(2):85-9. 
11. Arifna F, Ismy J, Yusuf H. Hubungan kepatuhan minum obat kelasi besi terhadap perkembangan seks sekunder pada anak penderita thalasemia beta mayor di Sentral Thalasemia RSUDZA Banda Aceh. J Ilm Mhs Medisia. 2017;2(3):13-17.

12. Fortin PM, Fisher SA, Madgwick KV, Trivella M, Hopewell S, Doree C, dkk. Interventions for improving adherence to iron chelation therapy in people with sickle cell disease or thalassaemia. Cochrane Database Syst Rev. 2018;2018(5). doi:10.1002/14651858.CDo12349.pub2

13. Fadlyana E, Ma'ani F, Elizabeth M, Reniarti L. Correlation between serum ferritin level and growth disorders in children with thalassemia. Am J Clin Med Res. 2017;5(3):31-5. DOI: 10.12691/ ajcmr-5-3-2.

14. Satria A, Ridar E, Tampubolon L. Hubungan derajat klinis dengan kadar feritin penyandang thalasemia $\beta$ di RSUD Arifin Achmad. Jom Fk. 2016;3(2):1-9.

15. Taher AT, Saliba AN. Iron overload in thalassemia: Different organs at different rates. Hematology. 2017;2017(1):265-71. doi:10.1182/ asheducation-2017.1.265

16. Guidelines for the Clinical Care of Patient with Thalassemia in Canada. [diunduh 13 April 2019]. Tersedia dari: http://www.thalassemia.ca/ wp-content/uploads/Thalassemia-Guidelines_ LR.pdf

17. Vekeman F, Sasane M, Cheng WY, Ramanakumar AV, Fortier J, Qiu Y, dkk. Adherence to iron chelation therapy and associated healthcare resource utilization and costs in Medicaid patients with sickle cell disease and thalassemia. J Med Econ. 2016;19(3):292-303. doi:10.3111/1369699 8.2015.1117979 